\title{
ANALYSIS VISIBILITY PARK AND RIDE TANGERANG DISTRICT (case study Cisauk Station)
}

\author{
Ayu Lestari, Tedy Murtejo, Nurul Chayati
}

Civil Engineering Departement Ibn Khaldun University Bogor, INDONESIA E-mail: ayuyuayu663@gmail.com

\begin{abstract}
Tangerang Regency is an area located in TatarPasundan, Banten Province, Indonesia. This area is located $30 \mathrm{~km}$ west of Jakarta and $90 \mathrm{~km}$ southeast of Serang. With an annual population growth rate of \pm 2.15 percent, the total population of Tangerang Regency in 2020 is $\pm 2,838,621$ according to the Central Statistics Agency (BPS) of South Tangerang Regency. South Tangerang Regency which has an area of 959.6 kilometers. This research was conducted to determine the fea sibility level of the Park and Ride development plan in Tangerang Regency. Traffic counting surv eys and interviews were carried out on main road sections which were then processed using Microsoft Excel to determine the parking accumulation until the fluctuation of motorbikes and cars was known. Furthermore, the interview data is processed to determine the amount of public interest in the development of Park and Ride which is reviewed based on gender, age, trip duration, trip intent, parking duration, monthly fuel expenditures, desired parking rates and those who agree to use Park and Ride when the survey was conducted. at 06.00-21.00 BBWI on the road in the Cisauk Station area. From the results of processing this data using Microsoft Excel, it was found that the characteristics of Park and Ride facilities users and also the number of users of Park and Ride facilities for motorbikes were 2349, while for cars of 272 with a plan age until 2021, this proves there is a need for increased interest in motorbikes. Park and Ride development at Cisauk Station, Tangerang Regency.
\end{abstract}

Key word: park and ride; cisauk station; transportation; facilities.

\begin{tabular}{cccc}
\hline Received: & Revised: & Accepted: & Available online: \\
$2020-10-08$ & $2020-10-22$ & $2020-11-10$ & $2021-10-20$ \\
\hline
\end{tabular}

\section{INTRODUCTION}

Tangerang Regency is an area located in TatarPasundan, Banten Province, Indonesia. This area is located $30 \mathrm{~km}$ west of Jakarta and $90 \mathrm{~km}$ southeast of Serang, the capital of Banten Province. In Tangerang Regency, it is a suitable area for the construction of Park and Ride, precisely at Cisauk Station with a strategic position and close to the city center, rice fields, etc.). According to Olaru (2013), Park and Ride is influenced by several times, namely departure time, congestion, public transportation services, modes of access, socio-economic characteristics, and Transit Oriented Development (TOD). There are two things to choose a Park and Ride location, first, it is necessary to identify a general area that can support one or more Park and Ride facilities (the use of standards will help determine the feasibility of the area), second, a specific location is chosen by assessing its characteristics such as road property space, atmosphere, location size, visibility, access, transit services, access road congestion, transit design forms, traffic circulation, bicycle access, and development potential(Chu, 2001).

As an industrial center area, most of the people involved in the economic sector in Tangerang Regency work in the industrial sector. In fact, the industrial sector absorbs more jobs than other sectors.

Paved roads will result in very stable vehicle traffic. Surface conditions using reinforced concrete will affect the collision between the tires and the road surface. The road surface will be smooth and comfortable, there will be no noise. while the bumpy road surface and lots of holes will affect the sound condition caused by both the exhaust, rough engine and friction between the vehicle body and the uneven surface (Akbardin.J.et.al, 2020; Syaiful.S, 2020; Syaiful.S, Akbardin.J, 2020; Syaiful.S, Andana,R,2021). Seeing the existing parking conditions at a station will affect the parking pattem. If a large and comfortable parking area is provided, then the traffic around it will be orderly and 
orderly. So that it can be said that the conditions that allow for ma neuvering so that the parking vehicle is in accordance with the actual conditions. This condition is supported by parking arrangements and heavy, medium or quiet tra ffic will look regular. Did not see the traffic conditions around it (Syaiful.S, Hariyadi.D, 2019; Syaiful.S, Lasmana.L, 2020; Saiful.S.et.al, 2020; Syaiful.S, Pratama.Y,2019; Syaiful.S, Yuliantino.M, 2017).

\section{RESEARCH METHODS}

This research was conducted at Cisauk Station, Tangerang Regency. The implementation of this research was started in May 2020.

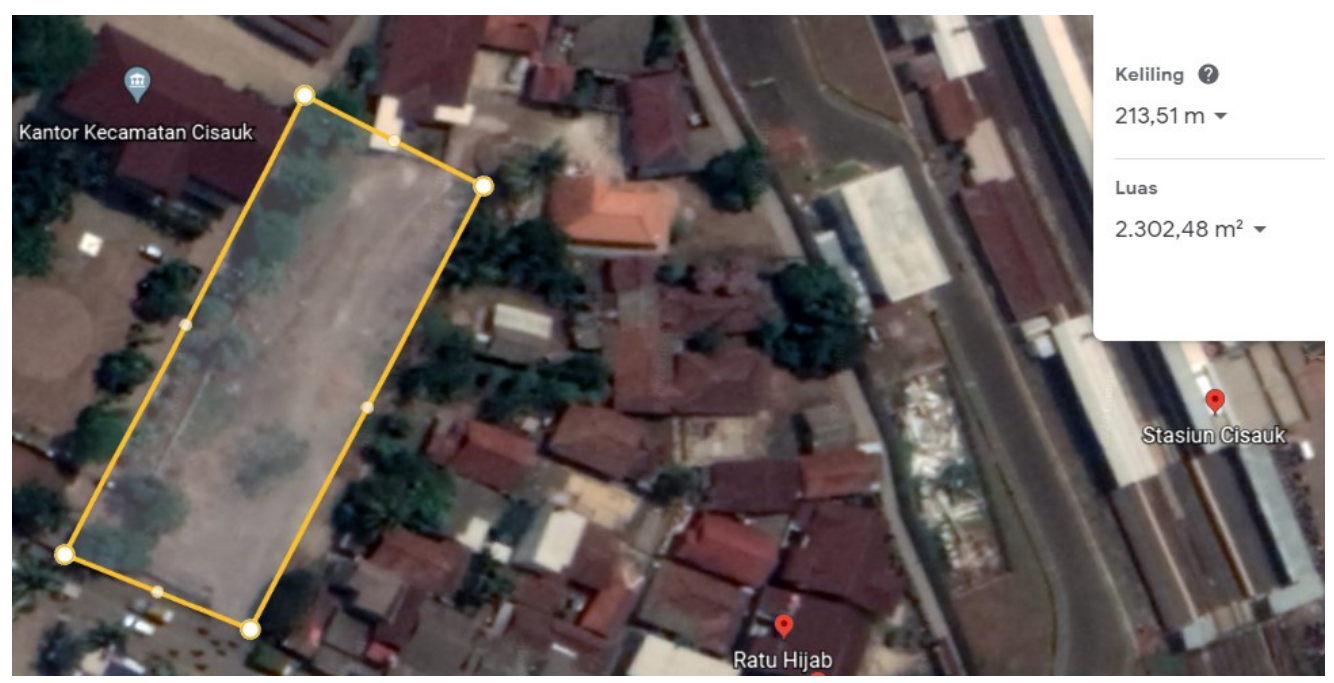

Figure 1. Map of the research location Source: Analysis results

The stages of this research are shown in the form of a flow chart as follows:

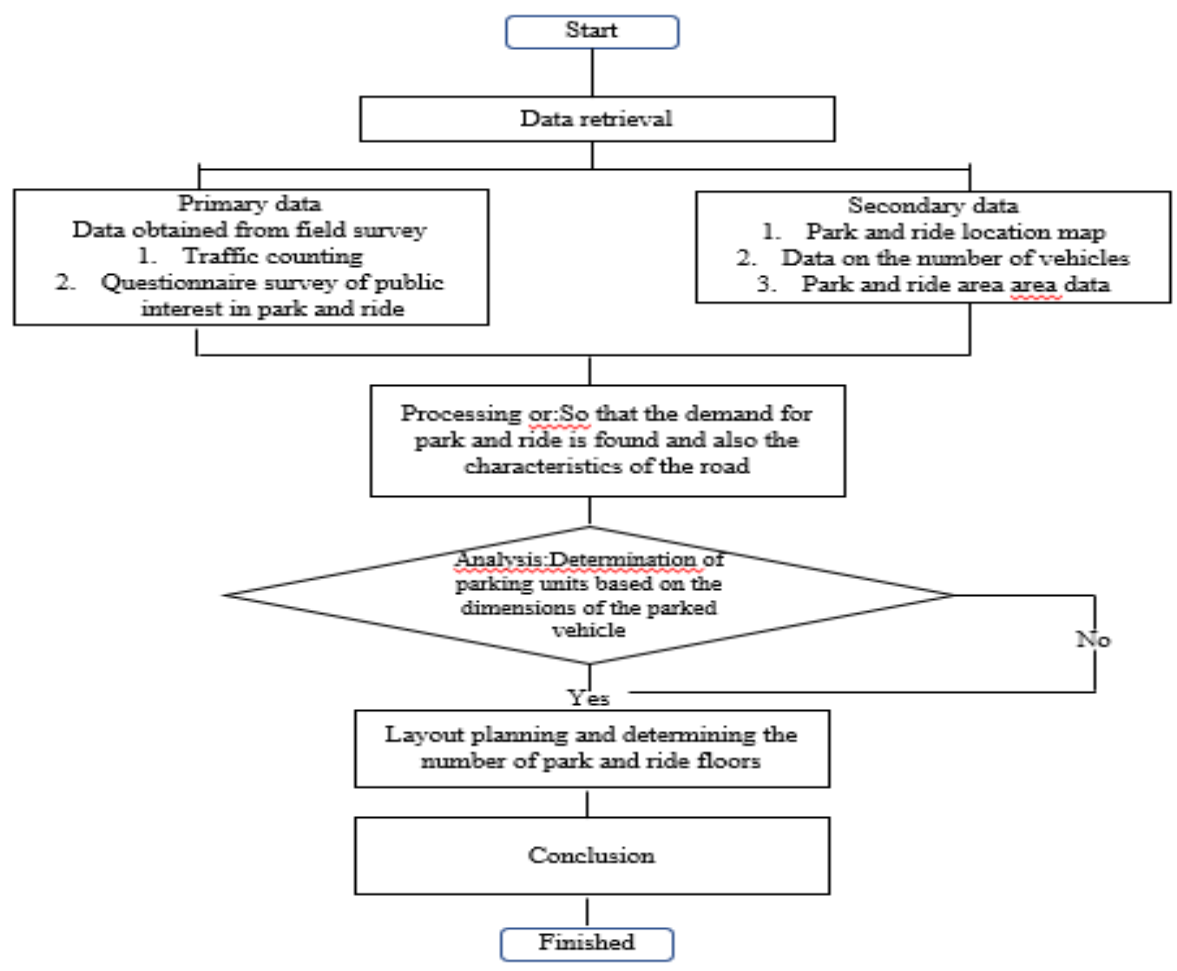

Figure 2. Research flow diagram 


\section{RESULTS AND DISCUSSION}

\section{Parking Characteristics}

The parking area at Cisauk Station consists of 2 zones, namely the northern and southern zones. The characteristics of the vehicles parked at Cisauk Station consist of two-wheeled and four-wheeled vehicles. The busiest parking location is in the parking lot north of the station.

The parking survey at Cisauk station was conducted for 12 hours (06:00 - 21:00) for four-wheeled and 2-wheeled vehicles.The following are the results of the parking survey for each zone in the Cisauk Station parking lot:

Table 1. Parking Survey of Cisauk Station

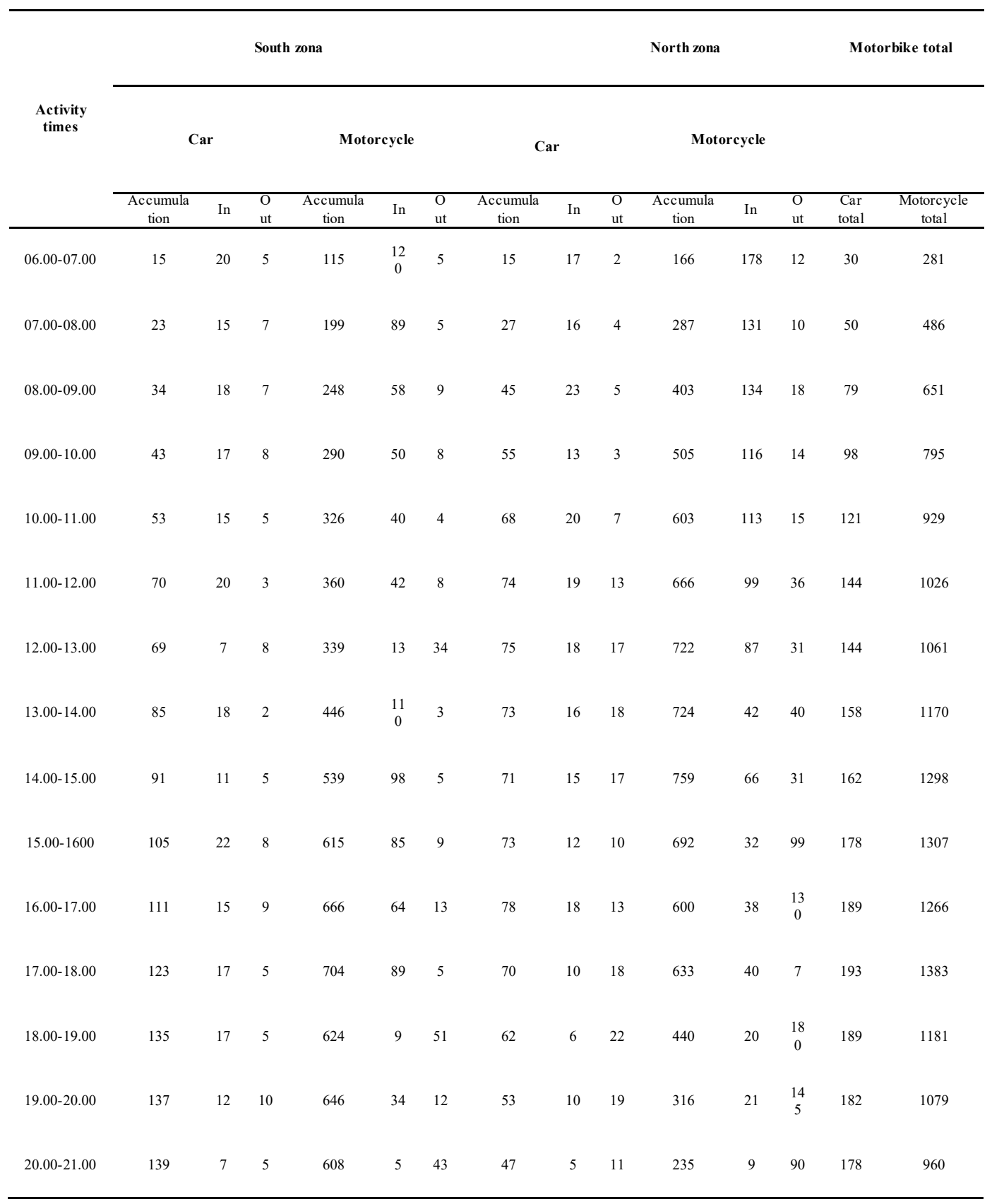




\begin{tabular}{|c|c|c|c|c|c|c|c|c|c|c|c|c|c|c|}
\hline Total & 1233 & $\begin{array}{c}23 \\
1\end{array}$ & 92 & 6725 & $\begin{array}{c}90 \\
6\end{array}$ & $\begin{array}{c}21 \\
4\end{array}$ & 886 & $\begin{array}{c}21 \\
8\end{array}$ & $\begin{array}{c}17 \\
9\end{array}$ & 7751 & $\begin{array}{c}112 \\
6\end{array}$ & $\begin{array}{c}85 \\
8\end{array}$ & 2095 & 14873 \\
\hline $\begin{array}{c}\text { Total } \\
\text { Fluktuation }\end{array}$ & 16595 & & & & & & & & & & & & & \\
\hline
\end{tabular}

Source: Survey and analysis results

\section{Parking Capacity}

Cisauk Station has the characteristics of using a parking area that is mixed between two-wheeled vehicles (motorbikes) and four-wheeled vehicles (private cars). So it is unclear the distribution of capacity for two-wheeled and four-wheeled vehicles. To calculate the parking capacity of Cisauk Station, it is done during peak hours, namely 15:00 to 16:00. Because at that hour the parking lot is used optimally.

The highest parking accumulation is at 17:00-18: 00 as many as 193 vehicles parked at Cisauk Station. That way the parking index or parking turnover rate can be calculated as follows:

\section{Level of Use of Parking Areas}

\section{Turn over}

Turn Over or the level of parking land use is obtained by comparing the number of parking vehicles with the parking capacity provided. Based on equation 2.4 , the turnover for cars is $449 / 238.1=$ 1.885 and for motorbikes $3023 / 1570.016=1.294$

\section{Parking Indeks}

The highest parking accumulation is at 17:00-18: 00 as many as 193 vehicles parked at Cisauk Station, Tangerang Regency. Based on equation 2.5, the parking index or parking turnover rate for cars is $449 / 193=2.326$ and for motorbikes is 1.469

\section{Analysis of the Traffic Impact of Park and Ride Development}

The capacity of each road section is obtained by calculating the data based on the manual method of Indonesian Highway Capacity (MKJI, 2017)

Table 2. Inventory Data and Calculation of Road Capacity).

\begin{tabular}{|c|c|c|c|c|c|}
\hline No & Path of Study & $\begin{array}{l}\text { Road } \\
\text { Width }\end{array}$ & Type & $\begin{array}{l}\text { Types of } \\
\text { side } \\
\text { barriers }\end{array}$ & $\begin{array}{l}\text { Capacity } \\
\text { (pcu/hour) }\end{array}$ \\
\hline 1 & Jl. Raya Cisauk Lapan & 12 & 4/2 UD & High & 5404,08 \\
\hline 2 & Jl. Raya Cisauk & 9 & 2/2 UD & Moderate & 3190 \\
\hline 3 & Jl. Cisauk-Serpong & 12 & 4/2 UD & Moderate & 5343,36 \\
\hline
\end{tabular}

\section{Road Section Performance Analysis}

As previously explained, the road performance assessment is carried out to see an overview of the existing traffic flow conditions that will be compared with the scenario of park and ride development. The performance assessment is carried out based on the results of the traffic counting 
survey and the geometric condition inventory data of the roads. The method used in assessing the performance of the road network is the 2017 MKJI which is generally carried out in traffic impact analysis studies in Indonesia. The VCR parameters in relation to road network performance are shown in the table below. These values will be used as VCR parameters determining the performance of the surveyed road network.

The performance of the Cisauk Station road section will decline during peak hours, when many vehicles are parked and in and out of the parking lot. The parking arrangement at Cisauk Station is less regular so that it often exceeds the predetermined parking limit.

\section{Land Use Survey}

In addition to the Traffic Counting survey, a land use survey was also carried out to determine the level of arrival and departure of vehicles after the construction of the Cisauk Station Park and Ride building. The generation and attractiveness of a development is largely determined by the land use that is being planned or established. To find out and predict the generation with the development of the area, a uniform land use survey was carried out with the plan to build the Cisauk Station Park and Ride building. The results of the land use survey are represented by the number of motorbikes, cars and other vehicles entering the area. The amount is compared with the existing area which is then calculated the ratio of expansion orper-unit generation

\section{Characteristics Of Road Service Level}

Service level LOS (Level Off Service) is a measure of the performance of a road or intersection which is calculated based on the level of road use, speed, density and obstacles that occur. In a mathematical form, the level of road service is indicated by the $\mathrm{V}-\mathrm{C}$ ratio versus the speed. The level of service is categorized from the best (A) - (F). Service level is the different operating conditions that occur on road lanes when accommodating various traffic volumes. And is a measure of the quality of the influence of traffic flow factors such as speed, travel time, obstacles, freedom of maneuver, driver comfort and indirectly operating costs and comfort (MKJI 1997, Urban Roads).

Table 3. Service level index (ITP) based on free flow speed

\begin{tabular}{cccl}
\hline Service Level & \% Of free speed & Traffic saturation level & \multicolumn{1}{c}{ Information } \\
\hline A & $\geq 90$ & $\leq 0,35$ & Free traffic \\
B & $\geq 70$ & $\leq 0,54$ & Stable \\
C & $\geq 50$ & $\leq 0,77$ & Still Limits Stable \\
D & $\geq 40$ & $\leq 0,93$ & Unstable \\
& $\geq 33$ & $\leq 1,0$ & Sometimes it gets \\
E & $<33$ & $>1$ & stuck \\
F & & & Forced / Bad \\
\hline
\end{tabular}

Source: MKJI Manualof Indonesian Road Capacity

Table 4. Categories of service levels before park and ride construction and after park and ride construction at Cisauk Station

\begin{tabular}{|c|c|c|c|c|c|c|c|c|c|}
\hline \multirow{2}{*}{ No } & \multirow{2}{*}{$\begin{array}{l}\text { Path of } \\
\text { study }\end{array}$} & \multicolumn{4}{|c|}{ Before Development } & \multicolumn{4}{|c|}{ Setelah Dibagun } \\
\hline & & Amount & Capacity & VCR & LOS & Amount & Capacity & VCR & LOS \\
\hline 1 & $\begin{array}{c}\text { Jl. Raya } \\
\text { Cisauk } \\
\text { Lapan }\end{array}$ & 2,310 & 5,303 & 0.44 & B & 2,380 & 5,303 & 0.45 & B \\
\hline
\end{tabular}




\begin{tabular}{|c|c|c|c|c|c|c|c|c|c|}
\hline 2 & $\begin{array}{l}\text { J1. Raya } \\
\text { Cisauk }\end{array}$ & 1,458 & 4,190 & 0.35 & B & 1,502 & 4,190 & 0.36 & B \\
\hline 3 & $\begin{array}{c}\text { Jl. } \\
\text { Cisauk- } \\
\text { Serpong }\end{array}$ & 2,160 & 4,232 & 0.51 & $\mathrm{C}$ & 2,225 & 4,232 & 0.53 & $\mathrm{C}$ \\
\hline
\end{tabular}

Source: Results of survey and a nalysis

\section{Interview}

An interview survey was conducted to determine the number of demands and also to determine the characteristics of park and ride users at Cisauk Station. The survey was conducted by conducting direct interviews with parking users who were carrying out activities in the station environment in the northern and southern zones of the sta tion a rea. Interviews were conducted between 6:00 am and 8:00 am within a few working days.

\section{Determination of the Number of Samples}

The number of samples was determined before conducting the interview survey. In this study, respondents are road users in the Cisauk station a rea, to get the number of respondents who will be able to represent the existing population. Therefore, the correct sample size is required.

The analysis uses the Slovin formula to calculate the percentage error of this interview survey. The Slovin formula is a formula or formula for calculating the minimum number of samples if the behavior of a population is not known with certainty. Therefore it requires the total volume of vehicles on motorbikes and cars.

Here is the Slovin formula:

$$
n=\frac{N}{N \cdot d^{2}+1}
$$

with:

$\mathrm{N}=$ Totalvolume of vehicles that cross the station area

$\mathrm{n}=$ Number of samples

$\mathrm{d}=$ Prediction error

Totalvehicle volume is the total number of vehicles passing through the surveyed roads in the traffic counting. Meanwhile, the Estimation Error in this study was determined at $13 \%$. After that it was calculated to determine the number of samples needed for the interview.

For the total volume of motorcycle vehicles, the traffic counting results were 27465 vehicles. Meanwhile, the totalvolume of cars was 13713 vehicles.

Based on the totalvolume of vehicles obtained from the traffic counting results, it can be calculated with the formula Slovin $n=27465 / 27465 \times 0.13+1=59$ for motorbikes and $n=13713 / 13713 \times 0.13$ $+1=58$ for cars.

Survey results on the number of potential park and ride users

Based on gender 


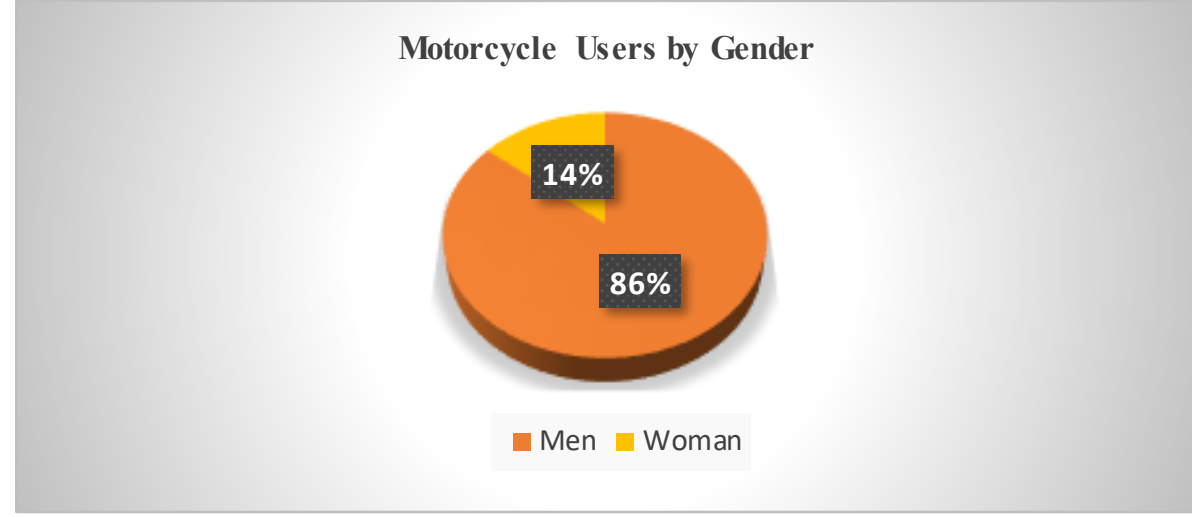

Figure 2. Diagram of motorcycle users by gender Source: Results of survey and analysis

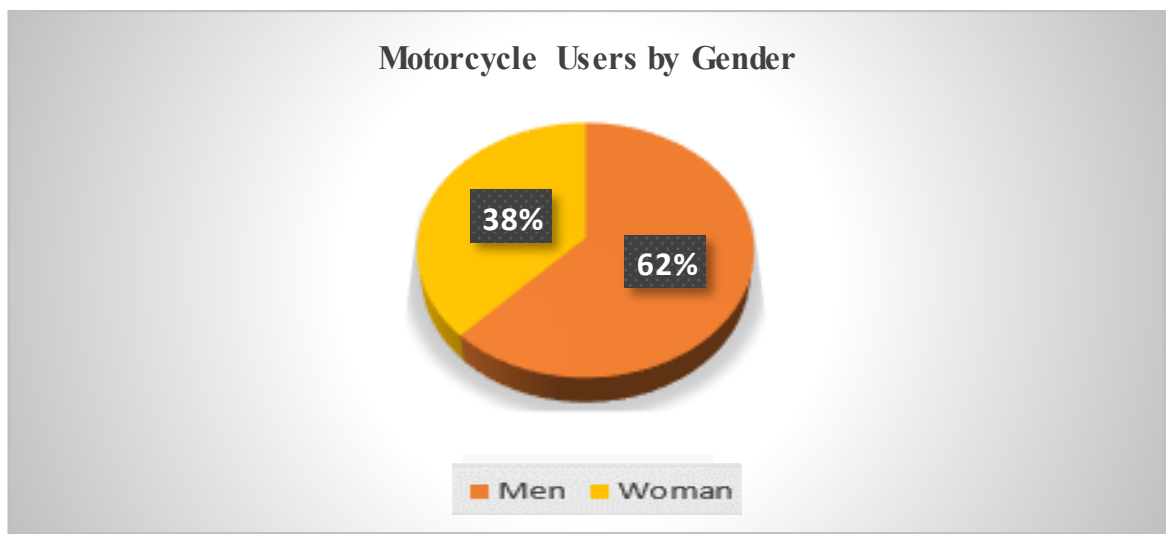

Figure 3. Diagram of motorcycle users by gender Source: Results of survey and analysis

\section{Based on age}

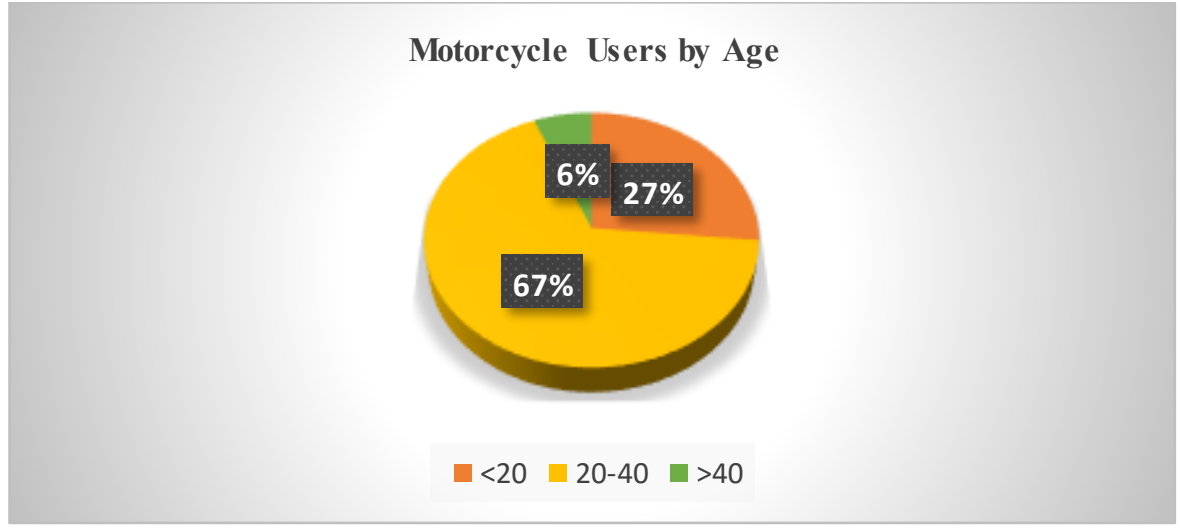

Figure 4. Diagram of motorcycle users by age Source: Results of survey and analysis 
Car Users by Age

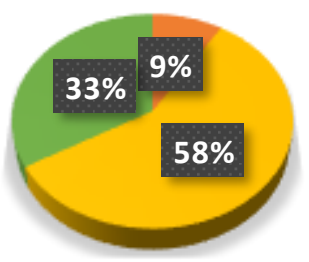

$\square$ 20 $20-40 \square>40$

Figure 5. Diagram of car users by age Source: Results of survey and analysis

Based on the duration of the trip

\section{Motorcycle Users Based on Trip Duration}

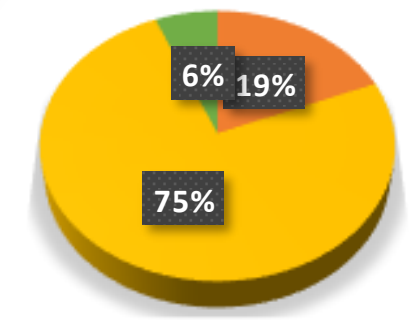

$\square<1$ hour $\square$ 1-2 hour $\square>2$ hour

Figure 6. Dia gram of motorcycle users based on trip duration Source: Results of survey and analysis

\section{Car Users Based on Trip Duration}

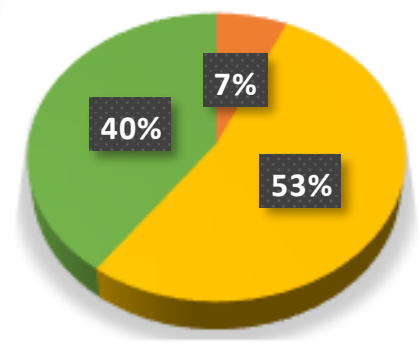

<1 hour $\square$ 1-2 hour $\square>2$ hour

Figure 7. Diagram of car users based on trip duration Source: Results of survey and analysis 


\section{Based on the purpose of travel}

\section{Motorcycle Users Based on Travel Purposes}

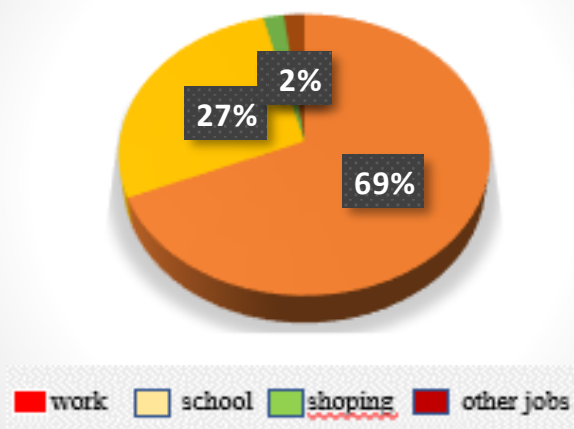

Figure 8. Diagram of motorcycle users based on travel purposes Source: Results of survey and analysis

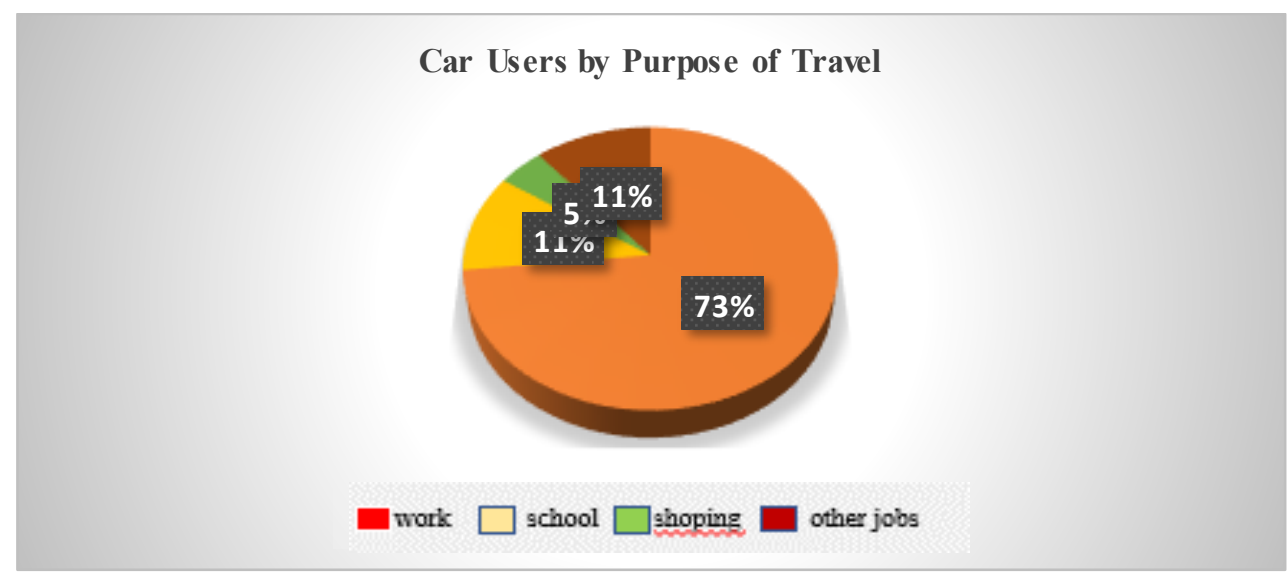

Figure 9. Dia gram of car users based on travel intent Source: Results of survey and analysis

\section{Demand park and ride}

In the interview results for motorcycles, it was found that the number of people who wanted to use the park and ride facilities was $74 \%$. Meanwhile, for cars, it was found that people who wanted to use park and ride facilities were $62 \%$.

\section{Estimated vehicle growth}

The growth of vehicles in this final project is planned for the next 5 years. The method used is the linear regression method. In this method, a deviation line is generated that can minimize the number of deviations from existing data. The data was processed using Microsoft Excel to produce linear regression equations in the form of mathematical equations.

The number of motorized vehicles in Tangerang is shown in table 9 in below.

Table 5. Number of motorvehicles in Tangerang

\begin{tabular}{ccc}
\hline Year & Motorcycle & Car \\
\hline 2012 & 850256 & 401456 \\
2013 & 903746 & 424689 \\
\hline
\end{tabular}




\begin{tabular}{lrl}
\hline 2014 & 956578 & 436297 \\
2015 & 1056753 & 446779 \\
2016 & 1137542 & 464245 \\
\hline
\end{tabular}

Source: Samsat 2016

\section{Motorcycle growth}

The data on the growth of motorcycles in South Tangerang Regency is processed using Microsoft Excel to produce graphs. From the graph, a mathematical equation is obtained. After that, the equation is used to get the value of the number of motorbikes until 2022. The following is a graph of the growth of motorbikes in Tangerang Regency.

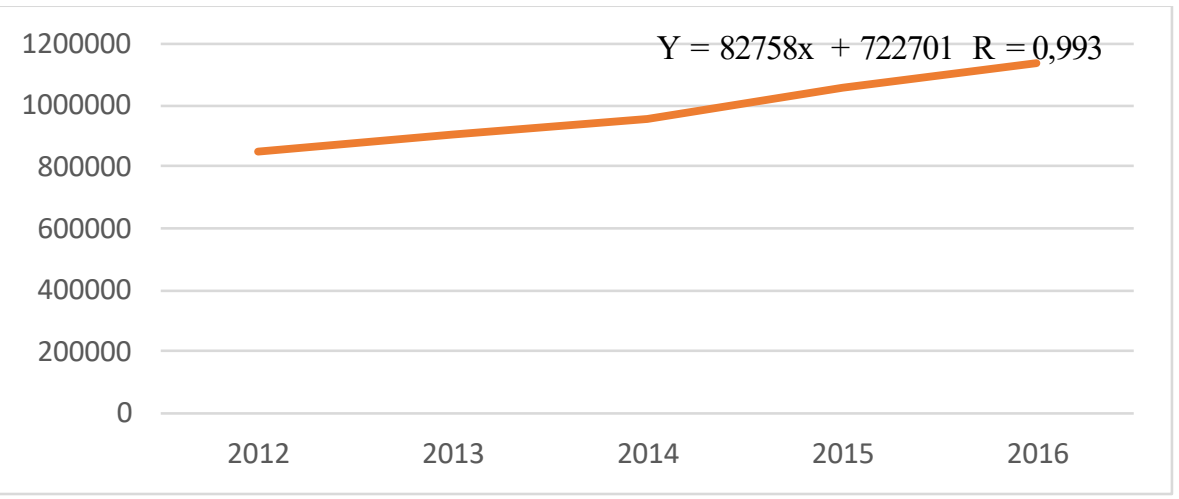

Figure 10. Regression graph of motorcycle growth Source: Survey and analysis results

\section{Car growth}

It's the same with motorbikes. Data on the growth of car vehicles in South Tangerang Regency are also processed using Microsoft Excel to produce graphs. The following is a graph of car growth in Tangerang Regency.

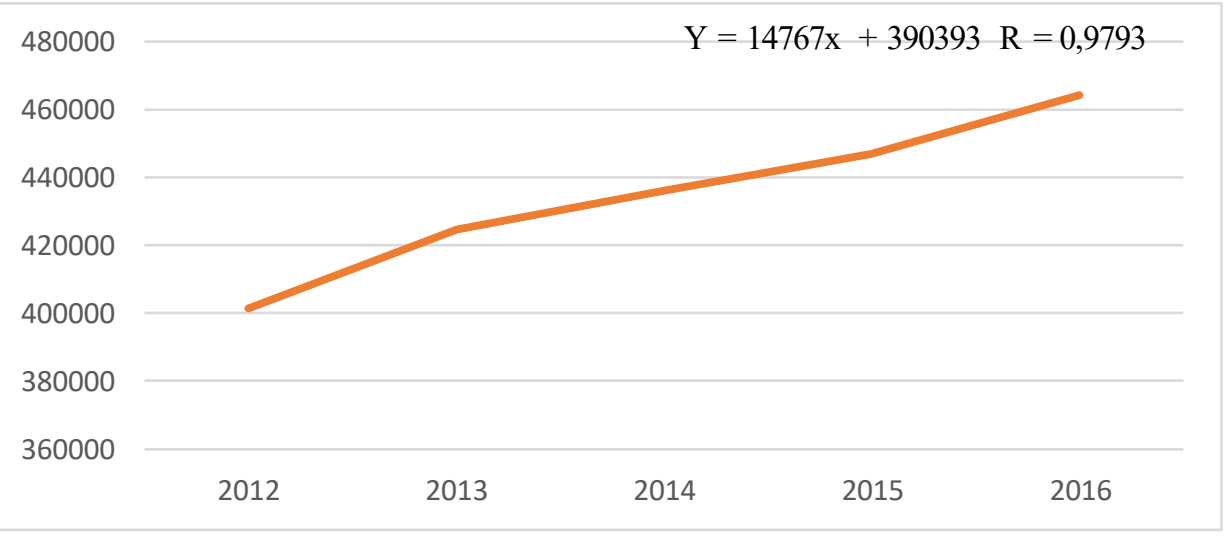

Figure 11. Growth regression graph for motorcycles Source: Survey and analysis results

\section{Estimated scenario revenue}

It is known that the first scenario is taken from the data from the highest preference survey data for car users with a maximum rate of 15 thousand rupiah, namely with a percentage of $63 \%$ and the highest preference for motor vehicle users with a maximum rate of 5 thousand rupiah, namely with a percentage of $68 \%$. As for the second scenario, parking rates are taken from the lowest rates.

\section{Estimated operating costs}


In the operation of the parking building, only a few main expense variables are estimated, namely the cost of employee salaries, electricity costs and maintenance costs.

The number of employees needed is twelve people with a system of dividing two working hours, namely 08: 00-15: 00 and 15:00-22: 00 hours. Each shift requires 6 employees, for the cost of electric power it is assumed to use 20 watt lamps.

\section{CONCLUSION}

Based on the results and discussion that have been described, the following conclusions can be drawn: Based on VCR analysis on roads that become accessibility for vehic les to and from the park and ride construction, if the park and ride construction is built, the lowest service level occurs on the Cisauk-Serpong road, with a service level of C. The results of the analysis using stated preference, it was found that the percentage of motorcyclists: $74 \%$ and the percentage of motorists: $62 \%$. The projection results of the increase in vehicles in Tangerang Regency, namely motorcycles by $5 \%$ and cars by $3 \%$ as well as data on potential park and ride users from the interview survey results in the maximum demand for motorcycles of 2,349 units and cars of 272 units.

\section{REFERENCES}

Anonymous, 1998, Directorate General of Land Transportation, Guidelines for Planning and Operation of Parking Facilities, Jakarta.

Ahmad Munawar. 2004. Urban Traffic Management. Yogyakarta: Beta Offset Publisher.

Abu Bakar, 2011, Parking Planning and operation of parking facilities, Jakarta, Transindo Ga stama Media.

Akbardin J., Parikesit D., Riyanto B., Mulyono A. T. \& Syaiful S. 2020. Modeling of trips assignment analysis for roads network system based on transportation needs of export commodity. ARPN Journal of Engineering and Applied Science. 15(21): 2463-2470. http://www.arpnjournals.org/jeas/research_papers/rp 2020/jeas 1120_8379.pdf

Directorate General of Highways, 1997, Manual of Indonesian Road Capacity (MKJ) (urban roads), Sweroad and PT. Bina Karya, Jakarta.

Fahmi, Khairul. (2014). Analyze parking space capacity. Pengaraian Sand City. APTEK Journal Vol. 6 No.1.

Syaiful S. 2020. Analysis on the Addition of Fiber the Strong Bending Mixed Concrete, ARPN Journal of Engineering and Applied Science. 15(6): 724-729. http://www.arpnjournals.org/jeas/research_papers/rp_2020/jeas_0320_8152.pdf

Syaiful S. 2021. Additional Betonmix To Increase The Strength Of Concrete Press. ARPN Journal of Engineering and Applied Science. 16(15): 1583-1589. http://www.arpnjournals.org/jeas/research_papers/rp_2021/jeas_0821_8652.pdf

Syaiful S. \& Akbardn J. 2020. Civil Engineering Students ‘ Conceptual Understanding On Centrifugal Force Implementation Through Geometrical Design Of Inter-City Road In Indonesia. International Journal Of Scientific \& Technology Research 9 (10), pp 345-349. https://www.ijstr.org/final-print/oct2020/Civil-Engineering-Students-Conceptual-UnderstandingOn-Centrifugal-Force-Implementation-Through-Geometrical-Design-Of-Inter-city-Road-InIndonesia.pdf

SyaifulS. \& Andana R. 2021. Passenger Car Speed Assessment Relationship To The Noise Caused. Astonjadro: Jurnal Rekayasa Sipil 10 (1), pp 41-49. http://ejournal.uikabogor.ac.id/index.php/ASTONJADRO/article/view/3494

SyaifulS. \& Elvira Y. 2017. Case Study On Use Area Parking At New Market City Shopping Center Bogor. IJTI (International Journal Of Transportation And Infrastructure), 1(1), 34-40. Retrieved from http://jurnal.narotama.ac.id/index.php/ijti/article/view/330 
Syaiful S \& HariyadiD. 2019. Case Study on Sustainable T-Jungtion Cibinong City Mall (CCM) in Bogor Indonesia. ARPN Journal of Engineering and Applied Science. 14(17): 2960-2971. http://www.arpnjournals.org/jeas/research_papers/rp_2019/jeas 0919 7895.pdf

Syaiful S. \& Lasmana L. 2020. Study about level of railway road damage railways with susta inable PCI method, ARPN Journal of Engineering and Applied Science. 15(8): 962-968. http://www.arpnjournals.org/jeas/research_papers/rp_2020/jeas 0420 8184.pdf

Syaiful S., Prayoga H. \& Akbardin J. 2020. Sustainable About The Need Of Parking Systems At The Mall RDS Bogor. ARPN Journal of Engineering and Applied Science. 15(22): 2620-2626. http://www.arpnjournals.org/jeas/research_papers/rp_2020/jeas_1120_8397.pdf

Syaiful S \& \& Pratama Y. 2019. Sustainable Studies about General Public Transport Performance in the City of Bogor. ARPN Journal of Engineering and Applied Science. 14(18): 3241 -3247. http://www.arpnjournals.org/jeas/research papers/rp 2019/jeas 0919 7925.pdf

Syaiful S. \& Yuliantino M. 2017. The Study Of Land Parking Mall Bogor Indah Plaza. Proceedings of the Conference on Global Research on Susta inable Transport (GROST 2017) ISSN: 2352 -5401, volume: 147 ISBN 978-94-6252-449-1. doi:10.2991/grost-17.2018.25 p. 286-303. https://www.atlantispress.com/proceedings/grost-17/25889389

State Ministry of Environment, 2009. Regulation of the State Minister for the Environment Number 8 of 2009 concerning Quality Standards for Wastewater for Businesses and / or Activities of Traffic Terminals Power Plants. Jakarta.

Tamin, O. Z (2008). Transportation Planning, Modeling \& Engineering: Theory, Sample Problems, and Applications. Bandung: ITB Bandung.

Tamin, O.Z. (1997). "Transportation Planning and Modeling", Civil Engineering, Bandung Institute of Technology.

Victoria Transport Policy Institute, 2010. Canadian Think Tank Seeking to Improve Transportation Planning and Transportation Policy. Canada.

Vuchic, V.R., 1976, Urban Public Transportation Systems and Technology, Prentice-Hall, Englewood Cliffs, New Jersey.

Warpani, Suwardjoko. 1990. Planning a Transport System. Bandung: ITB Publisher.

Warpani, P. Suwardjoko. (2002). Traffic and Road Transportation Management. Bandung. Publishers. 